University of Nebraska - Lincoln

DigitalCommons@University of Nebraska - Lincoln

USDA National Wildlife Research Center - Staff Publications
U.S. Department of Agriculture: Animal and Plant Health Inspection Service

2010

\title{
Reporting Difference for Colored Patagial Tags on Ring-Billed
}

\section{Gulls}

Thomas W. Seamans

USDA/APHIS/WS National Wildlife Research Center, thomas.w.seamans@aphis.usda.gov

Scott F. Beckerman

USDA/APHIS-Wildlife Services, Sc.Beckerman@aphis.usda.gov

John W. Hartmann

USDA/APHIS-Wildlife Services, John.W.Hartmann@aphis.usda.gov

James A. Rader

United States Department of Agriculture/Wildlife Services

Bradley F. Blackwell

US Department of Agriculture, bradley.f.blackwell@aphis.usda.gov

Follow this and additional works at: https://digitalcommons.unl.edu/icwdm_usdanwrc

Part of the Life Sciences Commons

Seamans, Thomas W.; Beckerman, Scott F.; Hartmann, John W.; Rader, James A.; and Blackwell, Bradley F., "Reporting Difference for Colored Patagial Tags on Ring-Billed Gulls" (2010). USDA National Wildlife Research Center - Staff Publications. 1286.

https://digitalcommons.unl.edu/icwdm_usdanwrc/1286

This Article is brought to you for free and open access by the U.S. Department of Agriculture: Animal and Plant Health Inspection Service at DigitalCommons@University of Nebraska - Lincoln. It has been accepted for inclusion in USDA National Wildlife Research Center - Staff Publications by an authorized administrator of DigitalCommons@University of Nebraska - Lincoln. 


\title{
Reporting Difference for Colored Patagial Tags on Ring-Billed Gulls
}

\author{
THOMAS W. SEAMANS, ${ }^{1}$ United States Department of Agriculture/Wildlife Services/National Wildlife Research Center/Obio Field Station, 6100 \\ Columbus Avenue, Sandusky, OH 44870, USA \\ SCOTT BECKERMAN, United States Department of Agriculture/Wildlife Services, 2869 Via Verde Drive, Springfield, IL 62703, USA \\ JOHN HARTMANN, United States Department of Agriculture/Wildlife Services, 2869 Via Verde Drive, Springfield, IL 62703, USA \\ JAMES A. RADER, ${ }^{2}$ United States Department of Agriculture/Wildlife Services, 2869 Via Verde Drive, Springfield, IL 62703, USA \\ BRADLEY F. BLACKWELL, United States Department of Agriculture/Wildlife Services/National Wildlife Research Center/Ohio Field Station, 6100 \\ Columbus Avenue, Sandusky, OH 44870, USA
}

\begin{abstract}
The possible role of tag color in mediating behaviors that could bias resighting rate has not been examined. In a study that began in 2007, we marked 725 ring-billed gulls (Larus delawarensis) with Bondcote royal blue, green, yellow, or orange patagial tags. Reports we gathered over 2 years indicated approximately a 3.4:1 bias in resighting rate toward yellow or orange tags. The observed bias is inconsistent with color-associated visibility bias or differential mortality among color-tagged breeding adults. Potential behavioral effects of tag color on individuals and conspecifics should be considered by biologists when planning marking studies.
\end{abstract}

KEY WORDS Great Lakes, Larus delawarensis, patagial tags, ring-billed gulls, tagging bias.

Banding or marking birds has long been recognized as an inexpensive yet viable means to determine local and longrange movements of birds (Wood 1945). However, marking techniques are not always benign. Calvo and Furness (1992) review multiple marking techniques and note effects of markers on birds, including initial discomfort, weight loss, impact on locomotion, changes in habitat choice, altered feeding behaviors, altered breeding ecology, susceptibility to predation, and changes in survival. In addition to potential negative effects on birds, the inability of observers to see tags may produce misleading results from studies that assume equal visibility of all tags (Sheaffer and Jarvis 1995, Skalski et al. 2005, Pauley and Crenshaw 2006). Clearly, biases associated with marking must be assessed within the context of study objectives, particularly the desired period for resighting marked birds.

Local movements of color-marked ring-billed gulls (Larus delawarensis; i.e., birds marked with patagial tags or dye), as well as some impacts of markers, have been documented (Southern 1971, Southern and Southern 1985, Kinkel 1989, Belant and Seamans 1993, Belant et al. 1993). Potential biases associated with spectrally similar colors (i.e., hues) or colors that might fade and be difficult to distinguish might influence study findings. In addition, colors, as birds perceive them, can also influence behavior. For example, red light (as we perceive light) has been shown to interfere with navigational ability in some birds (Wiltschko et al. 1993). Color of leg bands has been shown to hinder mate selection or the ability to retain territory in some bird species (Burley et al. 1982; Burley 1985, 1986; Hagan and Reed 1988; Metz and Weatherhead 1991).

However, potential effects of color on gull behavior, especially as related to bands or tags, have not been

\footnotetext{
${ }^{1}$ E-mail: thomas.w.seamans@USDA.gov

${ }^{2}$ Present address: 1228 Legends Club Drive, Mount Pleasant, SC 29466, USA
}

examined. For example, gulls have a tetrachromatic vision system that allows vision within the ultraviolet (UV) range $(<400 \mathrm{~nm})$ through $700 \mathrm{~nm}$ (Bowmaker et al. 1997, Hart et al. 1998, Ödeen and Håstad 2003, Håstad et al. 2005), and gulls are also capable of seeing in low-light conditions (Tinbergen 1960, Hailman 1964, Delius et al. 1972, Emond et al. 2006). Even gull chicks seem to respond to hue independent of any behavioral activity (Delius et al. 1972). The white plumage of various species within gulls is highly reflective from the near-UV through the visible spectrum. This reflective effect might serve in communication between conspecifics or as a means of concealment from potential prey by allowing the bird to blend with the scattered shortwavelength light in the sky during aerial foraging (Tickell 2003, see also Mullen 2006). The effect of placing colored tags on gulls therefore could result in unanticipated changes to behavior of a tagged individual or response of conspecifics to the individual.

We examined bias in existing resighting reports for ringbilled gulls marked with colored-patagial tags, a bias inconsistent with tagging effects previously reported (e.g., Southern and Southern 1985, Kinkel 1989, Belant and Seamans 1993). We note that findings reported herein are incidental to a separate gull-management study focusing on local movements of gulls, and are not based on an experiment designed specifically to quantify factors contributing to resighting bias. Our objectives were to summarize data from resighting reports of marked gulls relative to published data on marker effects on resighting rates, as well as potential negative effects of marker color (based on spectral analysis) on marked birds and conspecifics.

\section{STUDY AREA}

As part of a larger collaborative study in Chicago, Illinois, USA, by the City of Chicago and the United States Department of Agriculture Wildlife Services program, involving ring-billed gull response to an egg-oiling project, 
we captured nesting adults throughout nesting colonies on Dime Pier and Lake Calumet. Dime Pier was located on Lake Michigan in downtown Chicago $\left(41^{\circ} 40^{\prime} \mathrm{N}, 87^{\circ} 36^{\prime} \mathrm{W}\right)$ and accommodated about 3,100 nests. The Lake Calumet colony was on a dike in Lake Calumet $\left(41^{\circ} 53^{\prime} \mathrm{N}, 87^{\circ} 35^{\prime} \mathrm{W}\right)$ and contained about 31,400 nests.

\section{METHODS}

We captured nesting adults at the 2 colonies during April and May 2007 using walk-in traps (Weaver and Kadlec 1970). We determined sex and attached patagial tags on both wings and a standard leg band to captured birds (Southern 1971, Ryder 1978). In June 2007, we captured with dip nets and tagged local hatching-year birds just prior to fledging. All capture, handling, and tagging of gulls was approved by the United States Department of Agriculture, National Wildlife Research Center Institutional Animal Care and Use Committee (QA-1476). We made tags out of $610-\mathrm{g} / \mathrm{m}^{2}$ green, orange, royal blue, or yellow polyvinyl chloride-coated materials (Bondcote, Pulaski, VI; see spectral analysis of material below) with no alpha-numeric marking. We cut all tags into a dumbbell shape $18 \mathrm{~cm}$ long with $5.2-\mathrm{cm}$-diameter circles at the ends and with a $2-\mathrm{cm}^{-}$ wide strip between circles.

In 2007 we tagged gulls at Lake Calumet with royal blue tags if their eggs were not oiled and yellow tags if eggs were oiled (Rader et al. 2008). We tagged gulls at Dime Pier with green tags if their eggs were not oiled and orange if the eggs were oiled. We tagged 725 gulls in 2007 as follows: 150 adult gulls ( $72 \mathrm{~F}, 78 \mathrm{M}$ ) received orange tags; 150 adults (80 $\mathrm{F}, 70 \mathrm{M})$ received yellow tags; 128 adults $(53 \mathrm{~F}, 75 \mathrm{M})$ and 75 hatching year gulls (203 total) received green tags; 152 adults (81 F, $71 \mathrm{M})$ and 70 hatching year gulls (222 total) received royal blue tags.

In 2008 and 2009 we did not tag any gulls. All eggs in accessible nests were oiled regardless of tag color of nesting adults (Hartmann et al. 2009). We conducted spot counts of gulls at the colonies and surrounding areas $\geq 2$ times each week throughout the summers of 2008 and 2009. In addition, we used press releases and on-line announcements to local and regional birding organizations to request and collect reports on tagged gulls from the public from September 2007 to April 2009. For these counts, if one person observed one bird multiple times at the same location, we limited the count to one instead of multiple counts.

Because of initial indications of resighting bias, and because gulls see within the UV range, we quantified reflectance (\%) of color samples from material used for the patagial tags with a USB2000 Fiber Optic Spectrometer (Ocean Optics, Inc., Dunedin, FL), AIS MINIDT1000A broadband light source (Analytical Instrument Systems, Inc., Flemington, NJ), and Ocean Optics SpectraSuite Spectroscopy Platform software (Version NetBeans IDE 4.1). We illuminated each sample at $45^{\circ}$ to the surface. We secured the probe, connected to a $400-\mu \mathrm{m}$-diameter fiberoptic cable at approximately $0.5 \mathrm{~cm}$ from the surface, and measured reflectance at the same angle. Before measuring reflectance from the sample material, we recorded reflectance from a titanium-white diffuse reflectance standard and a dark reference. We then recorded reflectance from the sample material at $0.35-\mathrm{nm}$ intervals, an integration time of 15 mseconds, and with boxcar width set to zero. Because tags used on gulls abraded over time, faded from UV radiation, and became layered with dirt, our measurements on material not placed on birds serve only as indices of spectral reflectance of the material. We report only descriptive statistics of reflectance measurements.

\section{RESULTS}

Wavelength(s) associated with peak reflectance differed for each Bondcote color on tags (Fig. 1). We found differences between color categories (e.g., the darker colors being royal blue and green tags vs. the lighter yellow and orange tags) in reflectance within the portion of the UV spectrum (349.94$399.72 \mathrm{~nm})$ we considered $(\bar{x} \pm \mathrm{SD} \%$ reflectance $/ \mathrm{nm}$ : royal blue, $11.9 \pm 9.3 \%$; green, $11.5 \pm 9.5 \%$; yellow, $1.5 \pm 1.3 \%$; orange, $0.1 \pm 0.3 \%$; Fig. 1 ). We also found differences in reflectance among color categories within the range of gull vision (349.94-527.45 nm), the halfway point on the spectral range we considered $(\bar{x} \pm \mathrm{SD} \%$ reflectance/nm: royal blue, $49.6 \pm 30.2 \%$; green, $49.3 \pm 30.0 \%$; yellow, 7.9 $\pm 11.0 \%$; orange, $1.6 \pm 2.3 \%$ ).

Public reports of adult-tagged gulls came from 20 states and one Canadian province during the migration and overwintering period. Following the 2007 season, the period in which eggs from green- or blue-tagged individuals were not oiled, resighting reports indicated 2.8 times more yellow- (21) and orange-tagged (29) birds than royal blue(12) and green-tagged (6) birds (\% resighting $=16.5 \%$ of yellow- and orange-tagged birds vs. $4.0 \%$ of royal blue- and green-tagged birds). During the 2008 breeding season, we counted adult-tagged birds of all tag colors at both nesting colonies and found 3.4 times more yellow- (60) and orangetagged (96) birds than royal blue- (15) or green-tagged (31) birds (\% resighting $=52.0 \%$ of yellow- and orange-tagged ad vs. $17.1 \%$ of royal blue- and green-tagged ad). Following the 2008 breeding season, when $\geq 80 \%$ of all eggs were oiled at both colonies regardless of the tag status of the adults, resighting reports indicated 1.9 times more yellow- (19) and orange-tagged (21) birds than royal blue- (8) and greentagged (13) birds (\% resighting $=13.5 \%$ of yellow- and orange-tagged birds vs. $5.0 \%$ of royal blue- and greentagged birds). No gulls tagged in 2007 as hatching-year birds were observed by the public or biologists during 2008 . During the 2009 breeding season, we observed 3.5 times more yellow- (18) and orange-tagged (35) birds than royal blue- ( 7 ) or green-tagged (8) birds (\% resighting $=17.7 \%$ of yellow- and orange-tagged ad vs. $5.4 \%$ of royal blue- and green-tagged ad). Between the 2008 and 2009 breeding seasons, the reduction in resightings of adult birds was comparable between tag-color categories $(\%$ reduction $=$ $66 \%$ yellow- and orange-tagged ad vs. $67.4 \%$ royal blue- and green-tagged ad). No gulls tagged as hatching-year birds in 2007 were observed in 2009. 


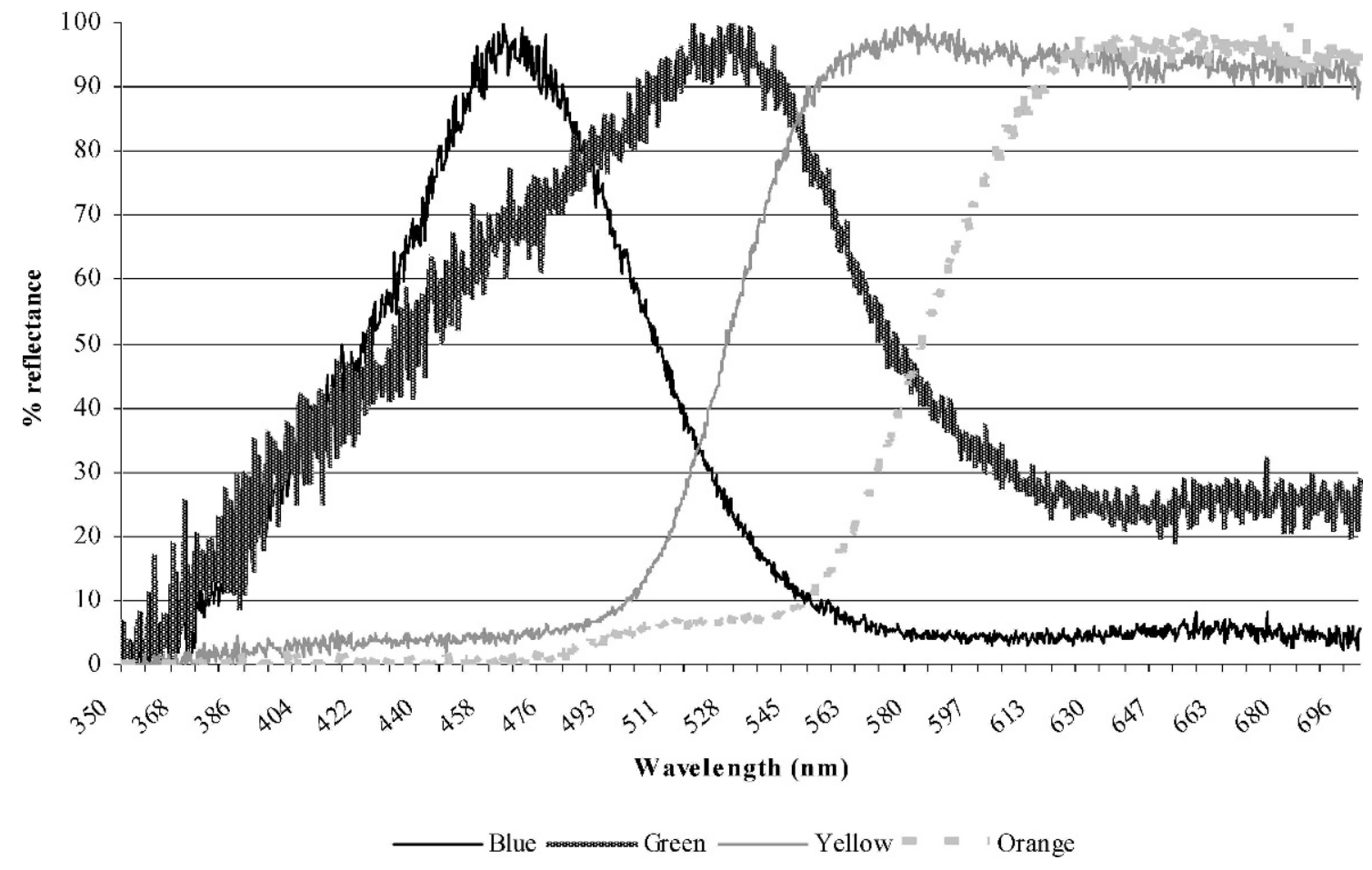

Figure 1. Percent reflectance of Bondcote material used for patagial tags for color-marking ring-billed gulls on breeding colonies in Chicago, Illinois, USA, April 2007-April 2009. We measured reflectance with a USB2000 Fiber Optic Spectrometer (Ocean Optics, Inc., Dunedin, FL), AIS MINIDT1000A broadband light source (Analytical Instrument Systems, Inc., Flemington, NJ), and Ocean Optics SpectraSuite Spectroscopy Platform software (Version NetBeans IDE 4.1)

Three tagged birds were reported by the public as dead (1 each of yellow, orange, and green) during the summer of 2007. In 2008 we found 2 green tags on the ground at Dime pier and these, based on their location, appeared to have come from 2 birds.

\section{DISCUSSION}

Resighting reports of ring-billed gulls marked with patagial tags at colonies in Chicago, Illinois, indicated a color bias that is not readily explained by color-associated visibility bias or negative effects of patagial tags on the survival of breeding adults. It is possible that birds marked with darker colors were less visible to observers and more likely overlooked (e.g., Kautz and Seamans 1992; Belant and Seamans 1993; Belant et al. 1993, 1998). However, in addition to public reports, professional biologists familiar with the color categories contributed resighting reports, particularly during breeding seasons. Thus, we contend that the $48 \%$ reduction in resightings of yellow- and orangetagged adult birds vs. the $83 \%$ reduction in resightings of royal blue- and green-tagged adults between the 2007 and 2008 breeding seasons cannot be attributed solely to visibility bias.

Oiling of gull eggs in the Chicago colonies caused $\geq 97 \%$ nests to fail while nests not oiled had no complete clutch loss (Rader et al. 2008). Therefore, tagged birds whose nests were not oiled during the 2007 breeding season (i.e., the royal blue- and green-tagged birds) may have incurred tag effects exacerbated by demands of successful breeding, which could have lowered survival between breeding seasons. For example, lower overwinter survival following successful breeding has been recorded for California gulls (Larus californicus; Pugesek and Diem 1990, 2008) and black-legged kittiwakes (Rissa tridactyla; Golet et al. 2004). However, multiyear data indicate that ring-billed gulls show strong site fidelity to breeding colonies, thus suggesting, as for northern fulmars (Fulmarus glacialis; Hatch 1987) and an earlier black-legged kittiwakes study (Cam et al. 1998), that overwinter survival of successful breeders is not significantly depressed (Southern 1977, Southern and Southern 1985, Ehrlich et al. 1988, Kinkel 1989). Moreover, the 17\% return rate for royal blue- and green-tagged adults at our colonies in 2008 is markedly below the $60 \%$ return rate previously reported for breeding patagial-tagged ring-billed gulls marked with yellow tags (Southern and Southern 1985, Kinkel 1989).

We suggest that the bias in resighting of our tagged gulls might be related to behavioral effects associated with the darker colored tags. Both blue and green tags had higher reflectance than yellow or orange tags in the UV range. Because gulls can see in this range (Ödeen and Håstad 2003, Håstad et al. 2005), this slight spectral difference might have influenced some subtle behavioral cue that we did not observe. For example, use of colored leg bands on some species of birds has resulted in territorial loss, lower reproductive success, altered mate selection, differential tag loss and differential mortality due to reproductive stress (DeHaven 1975, Burley et al. 1982, Hagan and Reed 1988, Metz and Weatherhead 1991). Mourning dove (Zenaida macroura) pair bonds were disrupted when yellow markers 
were placed on the heads of female doves, but not when green, white, or red marks were used (Frankel and Baskett 1963, Goforth and Baskett 1965). Also, Adelie penguins (Pygoscelis adeliae) pecked radio backpacks that contrasted with their plumage at greater rates than they pecked black packs (Wilson et al. 1990). A similar response by ring-billed gulls to royal blue or green tags could result in a differential loss of tags relative to yellow and orange tags, as well as in expected rates of tag loss (2-23\%; Kinkel 1989).

\section{Management Implications}

Observed bias associated with the resighting rates we found is extreme and unclear. Therefore, we suggest that use of color tags or dyes on gulls must be approached with caution and that care is taken to discern potential effects on behavior and survival, and subsequent resighting rates, of marked birds. Negative effects on tagged individuals or response to tag color by conspecifics will contribute to biased results and, possibly, poor management decisions.

\section{Acknowledgments}

We thank those who contributed to this project, including J. Coffee, S. Abu-Absi, birders from Chicago and across the United States for reporting their gull observations, and A. Spencer and numerous other Wildlife Services staff. We also thank the City of Chicago's Department of Environment and an anonymous landowner who granted us access to his or her property, as well as the Chicago Park District who allowed us to conduct observations on Chicago's beaches. We also thank T. DeVault, J. Schmidt, P. Schmidt, M. Stapanian, and B. Washburn for reviews of earlier versions of this manuscript.

\section{LITERATURE CITED}

Belant, J. L., S. K. Ickes, and T. W. Seamans. 1998. Importance of landfills to urban-nesting herring and ring-billed gulls. Landscape and Urban Planning 43:11-19.

Belant, J. L., and T. W. Seamans. 1993. Evaluation of dyes and techniques to color-mark incubating herring gulls. Journal of Field Ornithology 64:440-451.

Belant, J. L., T. W. Seamans, S. W. Gabrey, and S. K. Ickes. 1993. Importance of landfills to nesting herring gulls. Condor 95:817-830.

Bowmaker, J. K., L. A. Heath, S. E. Wilkie, and D. M. Hunt. 1997. Visual pigments and oil droplets from six classes of photoreceptor in the retinas of birds. Vision Research 37:2183-2194.

Burley, N. 1985. Leg-band color and mortality patterns in captive breeding populations of zebra finches. Auk 102:647-651.

Burley, N. 1986. Comparison of the band-colour preferences of two species of estrildid finches. Animal Behaviour 34:1732-1741.

Burley, N., G. Krantzberg, and P. Radman. 1982. Influence of colourbanding on the conspecific preferences of zebra finches. Animal Behaviour 30:444-455.

Calvo, B., and R. W. Furness. 1992. A review of the use and the effects of marks and devices on birds. Ringing and Migration 13:129-151.

Cam, E., J. E. Hines, J. Monnat, J. D. Nichols, and E. Danchin. 1998. Are adult nonbreeders prudent parents? The kittiwake model. Ecology 79:2917-2930.

DeHaven, R. W. 1975. Effect of color and attachment method on retention of leg tags by blackbirds. Western Bird Bander 50:48-50.

Delius, J. D., G. Thompson, K. L. Allen, and J. Emmerton. 1972. Colour mixing and colour preferences in neonate gulls. Experientia 28:12441246.
Ehrlich, P. R., D. S. Dobkin, and D. Wheye. 1988. The birder's handbook: a field guide to the natural history of North American Birds. Simon and Schuster, New York, New York, USA.

Emond, M. P., R. McNeil, T. Cabana, C. G. Guerra, and P. Lachapelle. 2006. Comparing the retinal structures and functions in two species of gulls (Larus delawarensis and Larus modestus) with significant nocturnal behaviours. Vision Research 46:2914-2925.

Frankel, A. I., and T. S. Baskett. 1963. Color marking disrupts pair bonds of captive mourning doves. Journal of Wildlife Management 27:124-127.

Goforth, W. R., and T. S. Baskett. 1965. Effects of experimental color marking on pairing of captive mourning doves. Journal of Wildlife Management 29:543-553.

Golet, G. H., J. A. Schmutz, D. B. Irons, and J. A. Estes. 2004. Determinants of reproductive costs in the long-lived black-legged kittiwake: a multiyear experiment. Ecological Monographs 74:353-372.

Hagan, J. M., and J. M. Reed. 1988. Red color bands reduce fledging success in red-cockaded woodpeckers. Auk 105:498-503.

Hailman, J. P. 1964. Coding of the colour preference of the gull chick. Nature 204:710.

Hart, N. S., J. C. Partridge, and I. C. Cuthill. 1998. Visual pigments, oil droplets and cone photoreceptor distribution in the European starling (Sturnus vulgaris). Journal of Experimental Biology 201:1433-1446.

Hartmann, J. W., S. F. Beckerman, T. W. Seamans, R. M. Engeman, and S. Abu-Absi. 2009. Report to the city of Chicago on conflicts with ringbilled gulls and the 2008 integrated ring-billed gull damage management project. Prepared for Chicago Department of Environment, Chicago, Illinois, USA.

Håstad, O., E. Ernstdotter, and A. Ödeen. 2005. Ultraviolet vision and foraging in dip and plunge diving birds. Biology Letters 1:306-309.

Hatch, S. A. 1987. Adult survival and productivity of northern fulmars in Alaska. Condor 89:685-696.

Kautz, J. E., and T. W. Seamans. 1992. Techniques for feral pigeon trapping, tagging and nest monitoring. North American Bird Bander 17:53-59.

Kinkel, L. K. 1989. Lasting effects of wing tags on ring-billed gulls. Auk 106:619-624.

Metz, K. J., and P. J. Weatherhead. 1991. Color bands function as secondary sexual traits in male red-winged blackbirds. Behavioral Ecology and Sociobiology 28:23-27.

Mullen, P. 2006. Spectrophotometric studies of avian plumage coloration with special emphasis on the ultraviolet range. Dissertation, Rheinischen Friedrich-Wilhelms-Universität Bonn, Deutschland.

Ödeen, A., and O. Håstad. 2003. Complex distribution of avian color vision systems revealed by sequencing the SWS1 opsin from total DNA. Molecular Biology and Evolution 20:855-861.

Pauley, G. R., and J. G. Crenshaw. 2006. Evaluation of paintball, markresight surveys for estimating mountain goat abundance. Wildlife Society Bulletin 34:1350-1355.

Pugesek, B. H., and K. L. Diem. 1990. The relationship between reproduction and survival in known-aged California gulls. Ecology 71:811-817.

Pugesek, B. H., and K. L. Diem. 2008. Timing and location of mortality of fledgling, subadult, and adult California gulls. Wilson Journal of Ornithology 120:159-166.

Rader, J. A., S. F. Beckerman, T. W. Seamans, and S. Beazley. 2008. Report to the city of Chicago on conflicts with ring-billed gulls and the 2007 gull damage management pilot project. Prepared for Chicago Department of Environment, Chicago, Illinois, USA.

Ryder, J. P. 1978. Sexing ring-billed gulls externally. Bird-Banding 49:218222.

Sheaffer, S. E., and R. L. Jarvis. 1995. Bias in Canada goose population size estimates from sighting data. Journal of Wildlife Management 59:464473.

Skalski, J. R., J. J. Millspaugh, and R. D. Spencer. 2005. Population estimation and biases in paintball, mark-resight surveys of elk. Journal of Wildlife Management 69:1043-1052.

Southern, W. E. 1971. Evaluation of a plastic wing-marker for gull studies. Bird-Banding 42:88-91.

Southern, W. E. 1977. Colony selection and colony site tenacity in ringbilled gulls at a stable colony. Auk 94:469-478.

Southern, L. K., and W. E. Southern. 1985. Some effects of wing tags on breeding ring-billed gulls. Auk 102:38-42.

Tickell, W. L. N. 2003. White plumage. Waterbirds 26:1-12. 
Tinbergen, N. 1960. The herring gulls's world. Harper and Row, New York, New York, USA.

Weaver, D. K., and J. A. Kadlec. 1970. A method for trapping breeding adult gulls. Bird-Banding 41:28-31.

Wilson, R. P., H. J. Spairani, N. R. Coria, B. M. Culik, and D. Adelung. 1990. Packages for attachment to seabirds: what color do Adelie penguins dislike least? Journal of Wildlife Management 54:447-451.
Wiltschko, W., U. Munro, H. Ford, and R. Wiltschko. 1993. Red light disrupts magnetic orientation of migratory birds. Nature 364:525527.

Wood, H. B. 1945. The history of bird banding. Auk 62:256-265.

Associate Editor: Green. 